\title{
Small business environment and development problems in the Russian Federation
}

\author{
Nina Kuznetsova ${ }^{1}$, Antonina Ilyina ${ }^{1}$, Maxim Mironov $^{1}$, Antonina Korolkova ${ }^{2}$, and \\ Tatiana Marinchenko, ${ }^{2 *}$ \\ ${ }^{1}$ Yuri Gagarin State Technical University of Saratov, 77 Politechnicheskaya Str., Saratov, 410054, the \\ Russian Federation \\ ${ }^{2}$ Russian Research Institute of Information and Feasibility Study on Engineering Support of Agribusi- \\ ness, the Federal State Budgetary Scientific Institution (Rosinformagrotekh FSBSI), 60, Lesnaya Str., \\ Pravdinsky Township, Moscow Region 141261, the Russian Federation
}

\begin{abstract}
The article presents an analysis of the small business environment and development in Russia, discusses state programs for the development of small and medium-sized businesses, a system of measures to support small businesses in the agricultural sector of the economy, and the role of franchising as one of the areas of small business development. The main problems of the development of small agribusiness, the introduction of innovations and the digital transformation of agricultural production in small export-oriented entrepreneurship are identified. The measures to improve the efficiency of small businesses, including these during the COVID-19 pandemic, are described.
\end{abstract}

\section{Introduction}

The economic growth of the national economy is unthinkable without the development of small and medium-sized businesses. The importance of its role in the development of the country's economic activity is undeniable. Small businesses contribute to an increase in employment, income growth, the development of innovation processes, and the competitiveness of the economy. The results of a study by economists indicate a direct relationship between the size of the small business sector, the well-being of the population and the growth of the country's economy. Small and medium business contributes to the expansion of the consumer sector, saturates the market with new goods and services, favors the growth of the country's export potential and the involvement of local raw materials in the economic turnover.

\section{Materials and methods}

The information base was statistical information from the Federal State Statistics Service of the Russian Federation, scientific organizations of the Russian Academy of Sciences (RAS) and the Ministry of Agriculture of the Russian Federation. Materials from research institutions, papers of leading domestic and foreign scientists in the field of research, and

${ }^{*}$ Corresponding author: 9419428@mail.ru 
regulatory and legal acts that establish strategic guidelines for the development of the country and the industry were used. The purposes of the study are the analysis and generalization of areas for the development of small forms of business, identification of problems of functioning of small businesses, development of measures to improve the system of state support for small and medium-sized businesses and to support exportoriented small agribusiness enterprises aimed at introducing innovations and digital technology.

\section{Results}

Currently, the share of small business in the Russia's GDP is over 21\%. This is more than 2.5 times lower than that in the developed countries of Europe and the United States. Regarding the number of small businesses per 100 persons of the population, Russia also lags far behind the highly developed countries. In recent years, small and medium-sized businesses in Russia have a tendency to develop and are represented by almost six million economic entities, which employ more than 18 million people. Russian small business is developed in such spheres of the economy as trade and the provision of various services, as well as in manufacturing, construction industries, and agriculture. According to 2019, trade accounts for $57 \%$, manufacturing accounts for $11 \%$, and agriculture accounts for $5.3 \%$ of the total turnover of Russian small and medium-sized businesses. The food industry and the primary processing of agricultural products (more than one trillion rubles) dominate in the processing industries followed by the production of metal products.

The development of small business in Russia is hindered by problems, the solution of which can reduce the risks of entrepreneurial activity. The most important issue for small business is the uncertainty of the economic situation, which is the first on the agenda when establishing a small business. The issue of high taxes and the uncertainty of demand for the results of small business activities are in the background. The next problem that significantly affects the activities of small businesses is the high interest rate on credit resources, the impossibility or difficulty in obtaining and using them, and the instability of the ruble exchange rate. When questioning, many small business representatives, when identifying constraining factors, put forward problems with start-up capital and high production costs, which are associated with constantly increasing tariffs for services and energy resources, rent, and interest rates on credit resources. The decisive issues for small and medium-sized agribusiness enterprises are the lack of professional qualified personnel and unfair competition on the part of monopolistic associations, imports and the shadow sector of the economy. An important obstacle is also the presence of bureaucratic delays, repeated unmotivated inspections and elements of corruption.

The above problems have led to a low level of small business contribution to the country's economy. Small businesses are directly dependent on market fluctuations and need comprehensive government assistance and support.

The problems of small business development require solutions not only at the federal, but also at the regional levels. The organizational and legal foundations of state support for small businesses have been developed at the federal level. A commission for the development of small businesses focused on supporting their competitiveness in the country's markets has been formed at the level of the government of the Russian Federation. Legal and organizational norms, which to a greater extent contributed to the development of small and medium-sized businesses, are regulated by the law No. 09-FZ titled "On the development of small and medium-sized businesses in the Russian Federation" dated 24.07.2007 [1].

In order to develop the small business sector as a factor in creating an up-to-date competitive economy of the country, a strategy for the development of small and medium- 
sized businesses in the Russian Federation for the period up to 2030 was developed and approved by the Order No. 1083-r of the Government of the Russian Federation dated June 2, 2016 [2]. The developed strategy is focused on the development of small innovative export-oriented business, with the help of which it is possible to improve the sectoral structure of the economy, the social sphere of the countryside, the level of employment, and to bring the share of the sector of small enterprises up to $40 \%$ in the country's GDP. It was planned to increase labor productivity two times, to increase the production output 2.5 times, to bring the share of the employed population to $35 \%$, and to bring the share of processing industries in the production output up to $20 \%$ in the small business sector by 2030.

A special place in the development strategy is given to improving financing of small and medium-sized enterprises (SME), expanding the availability of financial resources, creating a guarantee system, developing microfinance and long-term financing, leasing, and a cost subsidy system. A special place in solving the problem of collateral when issuing loans to entrepreneurs of small and medium-sized businesses is given to factoring, for which it has been supposed to develop standards and methods for assessing credit risks.

In order to develop intensively SMEs, federal programs for the development of small businesses in the Russian Federation have been developed and are being implemented [3]. In 2019, there were such targeted programs as:

- "Smarty" focused on the development of entrepreneurial activities of young people in the field of innovation, which involves the allocation of up to 500,000 rubles from budget funds per entrepreneur,

- "Start" focused on the development of startups and offering financial assistance in the amount of 2.5 million rubles, subject to $50 \%$ co-financing, to entrepreneurs involved in the development of up-to-date technology,

- "Development", the focus of which is the upgrading of production and the creation of new jobs with state support in the amount of up to 15 million rubles,

- "Internationalization", a program focused on the development of the export component and giving the opportunity to promote its products to world markets provided that their quality meets international standards,

- "Commercialization", which aims to increase production capacity and jobs with significant budgetary financial support,

- "Cooperation", which opens up the possibility of receiving up to 20 million rubles from the state budget for the development of production subject to improving the quality of goods manufactured.

As mentioned above, regional programs provide significant assistance in the development of small business apart from the federal ones [4]. Their implementation is manifested in the organization of business incubators, various types of funds, and support for export-oriented small businesses. Grant support has been developed, which is provided to an entrepreneur in the form of a subsidy in the amount of up to 600,000 rubles based on a competitive selection. Various funds can be established in the form of guarantee funds to be formed from the funds of the regional and federal budgets, or venture funds focused on supporting the implementation of innovations. In addition, the establishment of credit cooperatives and other microcredit organizations, entrepreneurship support centers, cluster development, technology parks and other centers will also contribute to the formation of an infrastructure to support the development of SMEs in the regions.

Multifunctional centers that provide consulting services to small businesses in obtaining financial state support are playing an important role in supporting the development of small businesses. Regarding the establishment of a small business by unemployed citizens, assistance is provided by employment centers, which, using the Program of the Ministry of 
Economic Development, can provide financial assistance in the amount of 12 times the maximum amount of unemployment benefits.

\section{Discussion}

A significant contribution to solving the problems of small business development in Russia in 2019 was made by the federal law No 185-FZ titled "On amending certain legislative acts of the Russian Federation in order to expand property support for small and medium-sized businesses" dated 03.07.2018, the main provisions of which make it possible to buy out state or municipal property and acquire land plots for lease [5]. The Government Decree No. 1212 dated 10.10.2018 is of great importance for the development of small business. The Decree provides an opportunity for budget subsidies for the amount of losses of credit institutions for the loans issued to SMEs to be obtained from the difference in preferential and commercial lending rates. The maximum loan amount provided at a preferential rate to a small business entity should not exceed 400,000 rubles for investment purposes, and their total amount is 1 billion rubles.

However, the implementation of the main indicators of the national project titled "Small and Medium Enterprises and Support for Individual Entrepreneurial Initiatives" intended for a period until 2024 [7] was under threat due to the coronavirus pandemic, which contributed to the government's development of emergency anti-crisis measures to preserve employment and support small businesses. These measures were focused on the expansion of preferential lending and introduction of deferrals for the payment of taxes, contributions, loans, and lease payments [8].

One of the areas reflected in the small business development strategy is the development of franchising. Franchising as an element of the development of small business in the sphere of services and trade involves interaction based on contractual relations between small businesses and large businesses. Under a franchising agreement, a representative of a large business (franchisor) shall provide small entrepreneurs (franchisee) with goods, technology, advertising services, and the right to use their brand and name on the market; small business representatives shall, while taking into account the peculiarities of a particular location, provide the franchisor with marketing and management services and may take part in investing in the activities of the parent company. The franchise market, which is represented by the Russian Franchising Association (RAF), began its development in Russia with the activities of Kodak and the functioning of a company that develops and maintains 1C accounting software, which currently has more than eight hundred small franchisees throughout the country. More than 500 franchisors and more than three thousand franchisees operate in Russia, with a turnover of more than $\$ 1.5$ billion. Retail trade is the leader on the franchising market of the Russian Federation, which accounts for about $50 \%$ of all franchisors in Russia. Franchising helps reducing the risks when setting up a small business due to supporting by a large company, provides a guarantee of timely delivery of goods, materials, and raw materials, in addition, large enterprises acquire the opportunity to penetrate local small markets, while obtaining information about changes in supply and demand. Franchising expands the possibilities for reducing the unemployment rate, reduces the influence of monopolistic structures, and promotes the development of competition. Currently, most often a foreign partner acts as a franchiser, and a Russian one acts as a franchisee in the franchising market. The disadvantages of Russian franchising also include the full orientation of small business activities to the interests of a large partner, the lack of freedom of action, and strict control by the franchisor.

In our opinion, franchising has great growth opportunities in this country, especially in the manufacturing sector. The prospects for the development of franchising in the Russian 
Federation are associated with the acceleration of the process of entry of independent small businesses into franchise networks with a promoted brand in order to increase their competitiveness.

The Government of the Russian Federation has identified priority areas in the development of SMEs. First of all, these are production and processing of agricultural products. According to the Federal State Statistics Service, there were 24,000 microenterprises, 205,000 farms, 23 million citizens with personal subsidiary plots, and 5,608 agricultural consumer cooperatives in the Russian Federation as of January 1, 2018. The share of peasant (farm) households (PFH) in the production of agricultural products in the Russian Federation increased from 12\% in 2018 to $13.6 \%$ in 2019. Growth in agricultural production in $\mathrm{KFH}$ amounted to $10 \%$ in 2019 . KFH accounted for 48 million hectares of sown areas or $60 \%$ of the total area. The share of small business increased to $64 \%$ in the sunflower production, to $28 \%$ in the vegetable production, $20 \%$ in the milk production, and $35 \%$ in the grain production [3]. For some regions, this share exceeds $50 \%$. In the first four months of 2020, the production output in the agricultural sector of the economy, according to the Federal State Statistics Service, increased by 3\% as compared to the same period in 2019 , including the $3 \%$ increase in April with a $12 \%$ decrease in the overall indicators of the country's economic development due to the COVID restrictions.

The growth of indicators of small businesses in the agricultural sector was ensured by solving the problems of financing small and medium-sized agribusiness even during the pandemic. So the interest rate on credit resources, both short-term and long-term ones, was reduced to 5\% per annum starting in 2017 [9]. Grant support under the 'Support for Startup Farmers' program has become widespread. Under this program, the amount of the grant can reach 3 million rubles, and 30 million rubles under the program for the development of family farms [10]. The development of small forms of farming in rural areas is facilitated by the subsidizing of part of the production costs in the livestock and crop growing industries, the costs associated with attracting credit resources for the purchase of modern agricultural machinery, equipment, animals, seeds, registration of real estate objects, land plots in ownership, as well as leasing payments and construction costs.

The development of small business was facilitated by the implementation of a new program to support agribusiness to start from 2019. According to the Decree No. 204 of the President of the Russian Federation dated May 7, 2018 titled "On national goals and strategic objectives of the development of the Russian Federation for the period up to 2024", the Ministry of Agriculture of Russia is implementing the federal project titled "A support system for farmers and the development of rural cooperation" [2, 3] within the framework of national project titled "Small and Medium Business and Support for Individual Entrepreneurial Initiatives." However, the implementation of the main areas of the new program is hindered by the spread of the coronavirus pandemic, which has led to an increase in prices for means of production (mineral fertilizers, seeds, plant protection products), and a reduction in the markets for meat, milk and vegetables. Self-isolation and a pandemic have significantly influenced the change in all components of the agricultural sector. Thus, a sharp decline in household income and instability in food prices contributed to a decrease in demand for food products of a high price segment (meat and dairy products, expensive fruits and vegetables) and an increase in the consumption of cereals, root crops, and potato, which leads to a change in customer requirements and creates a threat of the imbalance in nutrition and a decrease in the quality of the diet. According to experts, in the current conditions, it is necessary to develop new approaches to the formation of business models to adapt to the changing needs of the population, as well as to improve the strategy of the sales and promotion system of agricultural products using Internet resources. 
The transfer of many organizations and departments to a remote mode of operation and self-isolation caused problems with the preparation of documents for obtaining state support for small and medium-sized agribusiness in the form of subsidies, grants, etc. as well as loans at a preferential rate and leasing [11].

The authors propose to improve the procedure for registration and provision of subsidies, grants, concessional loans and leasing for small agribusiness inclusive of reducing the package of documents, to reduce the number of inspections and to determine the right of a small agribusiness entity, due to the seasonal nature of production, to set the deadlines for payment of value added tax by connecting them to the time of shipment and payment for products by the buyer, and to reduce the time frame for the provision of subsidies and grants.

Subjects of small agribusiness, as well as both small, and medium-sized businesses from other industries, strive to introduce innovative technology and digitalize processes in order to maintain competitiveness [12]. Some stably operating small and medium-sized agribusiness enterprises, while introducing all the latest scientific achievements into production processes and carrying out a digital transformation of their production, are also export-oriented when selling high-quality agricultural products to the countries of Asia, Africa and Europe [13, 14].

Despite numerous programs for the development of small and medium-sized businesses, including agrarian ones, we believe that the expansion of state support for such types of small and medium-sized agribusiness entities should be represented by a separate program. A program to support the development of small and medium-sized innovative exportoriented entrepreneurship in the agricultural sector should include the provision of interestfree loans, exemption from income tax charged for the income part that is aimed at introducing product and technological innovations, improving quotas for agricultural exports, improving the system of scientific and information provision, consulting and training employees in the agricultural sector, and reducing to zero interest rates on leasing when purchasing innovative machinery and equipment.

Improvement of leasing relations between the lessee and the lessor should take into account the use of innovative technology by small business entities, therefore, it is proposed to comprehensively equip agricultural enterprises that introduce innovative technology with leasing resource-saving equipment on preferential terms, but subject to more careful control over the efficiency of its use by the lessor.

The use of innovative machinery and equipment by small forms of farming in agriculture is difficult due to unsatisfactory local service. Therefore, in order to improve the timely guaranteed maintenance of innovative means of production, it is proposed to improve the maintenance and repair system through increasing the network of service centers of leasing companies to ensure high-quality maintenance of leasing and other machinery and equipment.

The priority right to receive preferential investment loans in the agricultural sector should also be granted to small and medium-sized innovative export-oriented entrepreneurship.

One of the areas of development of small and medium-sized businesses is the use of cooperative associations [15]. The development of small business in agricultural production is impossible without the formation and expansion of cooperative ties, since the small scale of production and sales of products within one economic entity limits the possibilities of business development, attracting investment funds, credit resources, and innovations, improving marketing activities, and the process of bringing finished products to the consumer performing service functions. Particular difficulties are observed in the sale of finished agricultural products and in expanding their share in regional, local, national and world agricultural and food markets [16]. State support measures contributed to the 
development and further formation of all forms of integration-cooperative formations, including such as agricultural consumer cooperatives for the sale of agricultural products, servicing small agribusiness entities and supplying them with means of production. It seems to us that cooperative formations will provide an opportunity for faster promotion and implementation of innovative digital technology in agricultural production by combining the efforts and resources of cooperation participants. The introduction of such technology requires large investment costs; however, the financial possibilities of small and mediumsized agribusiness for the purchase of agricultural machinery and equipment that would meet the requirements of the digital transformation of agricultural production are limited.

\section{Conclusion}

The measures proposed by the authors will improve the efficiency of small agribusiness, increase the rate of production, increase the efficiency of the introduction of innovative technology, digital transformation of agricultural production, reduce losses caused by the complication of the economic situation due to a pandemic, and ensure stability in food production and food security of the country.

\section{References}

1. Law No. 09-FZ of the Russian Federation "On the development of small and mediumsized businesses in the Russian Federation" dated 24.07.2007 https://www.garant.ru/products/ipo/prime/doc/70766584/

2. Order No. 1083-r of the Government of the Russian Federation "On the Strategy for the Development of Small and Medium-Sized Businesses in the Russian Federation for the Period up to 2030 and an Action Plan (Road Map) for its implementation" dated June 2, 2016 http://gimn272.spb.ru/doc/Nau.proekt.pdf

3. National report "On the progress and results of the implementation in 2019 of the State program for the development of agriculture and regulation of markets for agricultural products, raw materials food" https://mcx.gov.ru/upload/iblock/98a/98af7d467b718d07d5f138d4fe96eb6d.pdf

4. M.V. Israilov, M.R. Israilova, Bulletin of Scientific Thought of the Dagestan Territorial Institute of Professional Accountants 3, 121-125 (2020)

5. Federal Law No. 185-FZ 'On amendments to certain legislative acts of the Russian Federation in order to expand property support for small and medium-sized businesses' dated 03.07.2018 https://www.garant.ru/products/ipo/prime/doc/71879802

6. Decree No. 1212 of the Government of the Russian Federation 'On Amending the Rules for Granting Subsidies from the Federal Budget to Russian Credit Institutions to Reimburse Their Lost Income on Loans Granted to Small and Medium-Sized Businesses for Implementing Projects in Priority Industries at a Preferential Rate' dated October 10, 2018 https://base.garant.ru/72076756

7. Decree No. 204 of the President of the Russian Federation 'On national goals and strategic objectives of the development of the Russian Federation until 2024' dated 07.05.2018 http://gimn272.spb.ru/doc/Nau.proekt.pdf

8. S.P. Zemtsov, A.Y. Chepurenko, V.A. Barinova, A.N. Krasnoselskikh, Economic issues 10, 44-67 (2020) https://doi.org/10.32609/0042-8736-2020-10-44-67

9. N.M. Svetlov, R.G. Yanbykh, D.A. Loginova, Economic issues 4, 59-73 (2019) https://doi.org/10.32609/0042-8736-2019-4-59-73 
10. V.Y. Uzun, N.I. Shagaida, Economic issues 4, 39-58 (2019) https://doi.org/10.32609/0042-8736-2019-4-39-58

11. A.A. Yakovlev, N.V. Ershova, O.M. Uvarova, Economic issues 3, 47-62 (2020) https://doi.org/10.32609/0042-8736-2020-3-47-62

12. N. Bloom, J. Van Reenen, H. Williams, Economic issues 10, 5-31 (2019) https://doi.org/10.32609/0042-8736-2019-10-5-31

13. A.P. Korolkova, V.N. Kuzmin, T.E. Marynichenko, A.V. Goryacheva Support and Stimulation of Demand for Innovative Products and Technology in the Agribusiness (Moscow: Rosinformagrotekh, 2019)

14. N.A. Kuznetsova, A.V. Ilyina, A.M. Pukach Opportunities and problems of digital transformation of agricultural production of small and medium-sized businesses (Proceedings of the international scientific and practical conference "Digitalization of agriculture - development strategy", Ural State Agrarian University, 2019) https://www.atlantis-press.com/proceedings/ispc-19/articles

15. N.A. Kuznetsova, A.V. Ilyina, A.P. Korolkova, Machinery and equipment for rural area 9, 45-48 (2017)

16. V.A. Saraikin, R.G., Yanbykh, Bulletin of St. Petersburg University, Economy35 2, 251-268 (2019) 